\title{
EGG Quality Characteristics of Three Phenotypes of Local Chickens in Adamawa State.
}

\author{
A.G. Bobbo ; S. S. Baba ${ }^{* *}$ and M. S. Yahaya \\ *Dept, of Animal Science, Modibbo Adama University, Yola. \\ **Virology Dept, University of Maiduguri.
}

\begin{abstract}
The Experiment was designed to compare the internal and external egg quality traits of three phenotypes of village chickens. The study was carried out at Modibbo Adama University, poultry farm, Yola.The research lasted for a period of eight months. Three phenotypes of Sixteen (16) hens and Two (2) Cockerels each (48 breeder Hens and 6 Cocks) were purchased and assigned randomly for the study. A total of two hundred and seventy fertile eggs were collected for the study. Digital electric balance, Micrometer screw gauge and Varnier caliper were used to determine the parameters. Egg width, albumin height and width significantly $(p<0.001)$ differ among the phenotypes. Egg weight, yolk height, yolk index and haugh unit had a significant $(p<0.01)$ effect on all the phenotype. Egg length, egg index and shell weight had significant $(p<0.05)$ effect on the phenotype. The egg quality traits were significantly affected by the type of phenotypes except yolk width and shell thickness. Frizzle feathered consistently produced heavier, longer, wider egg and albumin and heavier shell. Similarly frizzle naked neck produced higher albumin and yolk height and haugh unit. Furthermore naked neck produced higher egg width, egg and yolk index and yolk height. Frizzle and Smooth feathered chickens and its associate produced significant positive and negative correlations in egg quality traits. Naked neck and it crosses produced significant positive correlation in all the egg quality traits studied. It could therefore be concluded that crossing between Frizzle and naked neck feathered chicken produced better egg quality traits required. I, recommend Frizzle Naked neck chickens to be considered for table eggs.
\end{abstract}

Key words: Phenotypes, egg quality, Varnier caliper, Digital electric balance, Micrometer screw gauge

\section{Introduction}

Quality has been defined by Kramer (1951) as the properties of any given food that have an influence or rejection of this food by the consumer. Egg quality is the general term which refers to general standards which define both internal and external quality such as egg weight, egg length, width, egg index, shell weight, shell thickness, albumin height, albumin width, yolk height, yolk index, haugh unit. Eggs and meat are amongst the most nutritious foods and eggs are rated with milk as one of the best protein foods rich in iron ( $\mathrm{Fe})$ and vitamins (Oluyemi and Roberts 2000). It has also been defined by Stadelmam, (1977) as the characteristics of eggs that affect its acceptability to the consumers and is more important price contributing factor in table and hatching eggs. The significance of the egg as a protein source for the nourishment of humans led to the consumers demand for some qualities in these nutrients (Uluocak et al., 1999). Therefore monitoring and evaluation of external and internal quality of chicken eggs is important in production economy and consumers' preferences for better quality of eggs. Islam et al. (2001) found that the external and internal egg quality traits of the breeds affect the future generations and their performance. Tumova et al. (2007) reported that genotype significantly affected the egg shape index, yolk and albumin quality and yolk index. Similarly, Yakubu et al. (2008) observed significant differences between naked neck and normal feathered in most of the egg parameters except shell weight and yolk index. Olawumi and Ogunlade (2008) reported highly significant correlation in most of the internal and external quality traits in exotic Isa brown layer breeders. Furthermore Yousria et al. (2010) reported significant positive correlation in most of the egg quality traits in Egyptian Gimmizah and Bandra and their crosses. The economic success of a laying flock solely depends on the total number of quality eggs produced. Approximately $7-8 \%$ of the total amount eggs are broken through the transfer of the eggs from the production to the consumer. Thus, the amount of cracked and broken eggs results in serious economical problems both for the producers, dealers and consumers (Hamilton, 1982). Peters et al., (2007) and Kul and Seke,r (2004) reported that egg weight and egg index are determinant of egg resistance to cracking and are considered very important traits when eggs are packed in container. Smith, (1990) reported the acceptable value for egg index as 0.75 and haugh unit at least $40 \%$ (Ayorinde et al., 1999). So far there are very limited research findings and dearth of information on the egg quality characteristics on different phenotypes of our village chickens in the state. The present study was undertaken to compare, assess and correlate the various egg quality characteristics in naked neck, frizzle and normal smooth feathered phenotypes of village chickens in Adamawa state. 


\section{Study Area}

\section{Materials And Methods}

The study was carried out in the Teaching and Research Farm of the Federal University of Technology, Yola. It is situated at Latitude 9 and 11 North and Longitude 11 and 14 East. The climate is tropical with distinct dry and wet season. The rainfall starts in April and ends in October while Dry season starts in November to March. The state has an annual rainfall of about $700 \mathrm{~mm}-1600 \mathrm{~mm}$ and relative humidity ranges from $5 \%-42 \%$ with the average temperature of $39^{0}$ (Adebayo and Tukur, 1999).

\section{Experimental Chickens}

Different phenotypes of experimental chickens were obtained from villages without the history of crossbreeding programmes involving exotic chickens and these represented the foundation stock. The chickens were placed on broad spectrum antibiotics, dewormed using Piperazine salt and treated for ectoparasites. From each phenotype 16 pullet layers and 2 cockerels were randomly selected for the study. The birds were placed on concrete floor full of saw dust at 16 hens per pen. The birds were exposed to natural day light feeding of about 12 hours per day. All the pullets were placed on grower die and fed at the rate of $80-90 \mathrm{~g} / \mathrm{bird} / \mathrm{day}$. The grower feed contained $15 \%$ crude protein and $2550 \mathrm{Kcal}$ Metabolizable energy (ME) per Kg of feed. Grower feed were gradually replaced with layer mash at point of lay (24 weeks). The layer mash contained $16.5 \%$ crude proteins and $2650 \mathrm{kcal} / \mathrm{kg}$ ME of feed. The chickens were provided with wooden laying boxes for laying. Egg collected twice a day at 10.00 am and $3.00 \mathrm{pm}$ (Appendix 4 and 5).

\section{Statistical analysis \\ Completely Randomized Design (CRD) design was used and all the data generated were analyzed using SPSS 13.0}

\section{Determination of internal and external egg quality characteristics}

A total of two hundred and seventy fertile eggs were collected from three phenotypes. Determination of external and internal egg quality traits were carried out immediately after collection, as described by (Fayeye $e t$ al., 2005). The parameters included egg weight egg length; egg width; egg index; yolk weight; yolk height; yolk diameter; yolk index; shell weight shell thickness albumen height; albumen width and haugh unit. Digital electric balance was used in weighing the eggs. Egg length and width were measured with the aid of pair of Varnier caliper (mm). The values of Egg length and Egg weight were used to determine the Eggs index. The thickness of each shell was determined using the micrometer screw gauge $(\mathrm{mm})$. The yolk and albumen height and width were determined by using pair or Varnier caliper calibrated in (mm) Accuracy of shell thickness was determined by measuring shell samples at the broad and middle portion and narrow end of the shell. The average shell thickness was then recorded in ( $\mathrm{mm})$. Yolk index was determined as a ratio of the yolk height to yolk width. The egg shape index, yolk index and haugh unit were calculated using the relationship below.

Egg shape index $(\%)=[$ width $(\mathrm{cm}) /$ length $(\mathrm{cm})] \times 100 \%$

Yolk index $(\%) \quad=[$ yolk height $(\mathrm{mm}) /$ yolk diameter $(\mathrm{mm})] \times 100 \%$

Haugh unit $(\mathrm{Hu}) \quad=100 \log (\mathrm{H}+/ \mathrm{G}(30 \mathrm{w}$ o.37-100)+19]/100\%

Where

$\mathrm{HU}=$ Haugh units

$\mathrm{HA}=$ observed albumin height $(\mathrm{mm})$

$\mathrm{G}=$ gravitational constant 32.2

$\mathrm{W}=$ observed weight of egg

\section{Effect of Hen of Different Phenotypes on Egg Quality:}

\section{Results}

Results of egg quality traits of nine phenotypes of local chickens are presented in Table 1 . The results indicated that all the parameters were significantly affected by the type of phenotypes except yolk width and shell thickness.

Frizzle feathered consistently produced heavier, wider egg and albumin and heavier shell. Similarly naked neck produced higher egg index yolk height and yolk index. Egg weight had a significant $(p<0.01)$ effect on all the phenotype with 45.04, 41.90, 40.82, 41.59, 41.66, 39.64, 40.71, 37.80 and 38.44g for frizzle x frizzle, frizzle x naked neck, frizzle x smooth, naked neck x naked neck, naked neck x frizzle, naked neck x smooth, smooth $x$ smooth, smooth $x$ naked neck, smooth $x$ frizzle respectively. Egg length had a significant $(p<0.05)$ effect on the phenotype being 5.05, 4.98, 4.96, 5.28, 5.38, 4.96, 5.04, 4.85 and 4.94cm for frizzle x frizzle, frizzle x naked neck, frizzle x smooth, naked neck x naked neck, naked neck x frizzle, naked neck x smooth, smooth x smooth, smooth x naked neck, smooth x frizzle respectively. Egg width similarly had a significant $(p<0.001)$ effect on the phenotype with $3.95,3.78,3.76,3.94,3.70,3.74,3.76,3.66$ and $3.69 \mathrm{~cm}$ for frizzle $x$ 
frizzle, frizzle $\mathrm{x}$ naked neck, frizzle $\mathrm{x}$ smooth, naked neck x naked neck, naked neck x frizzle, naked neck $\mathrm{x}$ smooth, smooth $\mathrm{x}$ smooth, smooth $\mathrm{x}$ naked neck, smooth $\mathrm{x}$ frizzle respectively. Egg index had a significance $(\mathrm{p}<0.05$. $)$ effect on all the phenotype studied with 77.61, 76.25, 76.09, 79.69, 74.18, 74.71, 75.90, 73.80 and $74.79 \%$ for frizzle $\mathrm{x}$ frizzle, frizzle $\mathrm{x}$ naked neck, frizzle $\mathrm{x}$ smooth, naked neck $\mathrm{x}$ naked neck, naked neck $\mathrm{x}$ frizzle, naked neck x smooth, smooth $\mathrm{x}$ smooth, smooth $\mathrm{x}$ naked neck, smooth $\mathrm{x}$ frizzle respectively. Albumin height and albumin width had a significance $(\mathrm{p}<0.001)$ effect on the phenotype with $6.51,9.19,7.41,6.80,7.43$, $7.51,6.66,7.11,7.03$, and $6.25,5.31,5.70,6.01,5.76,5.84,5.86,5.26$ and $5.19 \mathrm{~mm}$ for frizzle $\mathrm{x}$ frizzle, frizzle $\mathrm{x}$ naked neck, frizzle x smooth, naked neck x naked neck, naked neck x frizzle, naked neck x smooth, smooth $\mathrm{x}$ smooth, smooth $\mathrm{x}$ naked neck, smooth $\mathrm{x}$ frizzle respectively. Yolk height had a significant $(\mathrm{p}<0.01)$ effect on all the phenotype with $1.60,1.67,1.46,1.67,1.45,1.60,1.60,1.53$ and $1.56 \mathrm{~mm}$ respectively for frizzle $\mathrm{x}$ frizzle, frizzle $\mathrm{x}$ naked neck, frizzle $\mathrm{x}$ smooth, naked neck x naked neck, naked neck x frizzle, naked neck x smooth, smooth $\mathrm{x}$ smooth, smooth $\mathrm{x}$ naked neck, smooth $\mathrm{x}$ frizzle respectively. Yolk width is not statistically significant in all phenotype studied. Yolk index had a significant $(\mathrm{p}<0.01)$ effect on all the phenotypes with $41.64,43.61$, $36.45,45.92,37.78,42.89,41.72,39.35$ and $39.99 \%$ respectively for frizzle $\mathrm{x}$ frizzle, frizzle $\mathrm{x}$ naked neck, frizzle x smooth, naked neck x naked neck, naked neck x frizzle, naked neck x smooth, smooth $\mathrm{x}$ smooth, smooth $\mathrm{x}$ naked neck, smooth $\mathrm{x}$ frizzle respectively. Shell weight had a significant $(\mathrm{p}>0.01)$ effect on all the phenotypes studied with $5.114 .06,4.01,4.01,4.27,3.69,4.13,3.63$ and $3.99 \mathrm{~g}$ respectively for frizzle $\mathrm{x}$ frizzle, frizzle x naked neck, frizzle x smooth, naked neck x naked neck, naked neck x frizzle, naked neck x smooth, smooth $\mathrm{x}$ smooth, smooth $\mathrm{x}$ naked neck, smooth $\mathrm{x}$ frizzle respectively. Haugh unit also had a significant ( $>>0.01)$ effect with $85.13,100.50,91.30,91.86,91.06,92.18,90.35,90.54,89.96$ respectively for frizzle $\mathrm{x}$ frizzle, frizzle $\mathrm{x}$ naked neck, frizzle $\mathrm{x}$ smooth, naked neck x naked neck, naked neck x frizzle, naked neck $\mathrm{x}$ smooth, smooth x smooth, smooth $\mathrm{x}$ naked neck, smooth $\mathrm{x}$ frizzle respectively (Table 1).

In this study (Table 2), significant negative correlation was found between haugh unit and egg weight $(p<0.05)$, albumin height and egg width $(p<0.01)$, haugh unit and egg width $(p<0.01)$, haugh unit and shell weight $(p<0.01)$, yolk height and shell thickness $(p<0.05)$, yolk index and shell thickness $(p<0.05)$.

In this study (Table 3), significant positive correlation were found between haugh unit and albumin height $(\mathrm{p}<0.01)$, yolk index and yolk height $(\mathrm{p}<0.01)$ and some significant negative correlation between albumin width and albumin height $(p<0.01)$, haugh unit and albumin width $(p<0.01)$, yolk index and yolk width $(p<0.01)$.

In this study (Table 4), significant positive correlation was found between egg length and egg weight $(p<0.01)$, egg width and egg weight $(p<0.01)$, shell weight and egg weight $(p<0.01)$, egg width and egg length $(p<0.05)$, shell weight and egg length $(\mathrm{p}<0.01)$, egg index and egg width $(\mathrm{p}<0.05)$, shell weight and egg width $(\mathrm{p}<0.01)$ and a significant negative correlation was observed between egg index and egg length $(\mathrm{p}<0.05)$.

In this study (Table 5), significant positive correlation was found between albumin height and egg weight $(p<0.01)$, yolk height and egg weight $(p<0.01)$, yolk width and egg weight $(p<0.01)$, haugh unit and egg weight $(\mathrm{p}<0.01)$, yolk width and egg length $(\mathrm{p}<0.01)$, albumin height and egg width $(\mathrm{p}<0.01)$, yolk height and egg width $(\mathrm{p}<0.01)$, yolk width and egg width $(\mathrm{p}<0.01)$, yolk index and egg width $(\mathrm{p}<0.01)$, haugh unit and egg width $(p<0.01)$, yolk height and egg index $(p<0.05)$, haugh unit and egg index $(p<0.01)$, albumin height and shell weight $(p<0.01)$, yolk width and shell weight $(p<0.05)$, haugh unit and shell weight $(p<0.01)$, albumin height and shell thickness $(p<0.01)$, yolk width and shell thickness $(p<0.05)$, haugh unit and shell thickness, $(\mathrm{p}<0.01)$

In this study (Table 6), significant positive correlation was found between yolk height and albumin height $(p<0.05)$, haugh unit and albumin height $(p<0.01)$, yolk width and albumin width $(p<0.01)$, haugh unit and yolk height $(p<0.05)$, yolk index and yolk width $(p<0.01)$, haugh unit and yolk height $(p<0.05)$, haugh unit and yolk index $(\mathrm{p}>0.05)$.

In this study (Table 7), significant positive correlation was found between egg length and egg weight $(\mathrm{p}<0.01)$, egg width and egg weight $(\mathrm{p}<0.01)$,shell weight and egg weight $(\mathrm{p}<0.01)$,shell thickness and egg weight $(p>0.01)$, egg width and egg length $(p<0.05)$, shell weight and egg length $(p<0.05)$, egg index and egg width $(p<0.01)$, shell weight and egg width $(p<0.01)$, shell thickness and egg width $(p<0.05)$, shell thickness and shell weight $(\mathrm{p}<0.01)$.

In this study (Table 8), significant positive correlation was found between albumin width and egg weight $(p<0.01)$, yolk height and egg weight $(p<0.05)$, albumin width and egg width $(p<0.05)$, albumin width and shell weight $(p<0.01)$, albumin height and shell thickness $(p<0.01)$, haugh unit and shell thickness $(p<0.01)$ and also some significant negative correlation between albumin height and egg length $(p<0.05)$ haugh unit and egg length $(p<0.01)$, albumin height and shell weight $(p<) .05)$.

In this study (Table 9), significant positive correlation was found between haugh unit and albumin height $(\mathrm{p}<0.01)$, yolk index and yolk height $(\mathrm{p}<0.01)$ and also some significant negative correlation between albumin width and albumin height $(\mathrm{p}<0.01)$, yolk width and yolk height $(\mathrm{p}<0.05)$, yolk index and yolk width $(\mathrm{p}<0.01)$. 
In this study (Table 10), significant positive correlation was found between egg length and egg weight $(\mathrm{p}<0.01)$, egg width and egg weight $(p<0.01)$, shell weight and egg weight $(p<0.05)$,egg index and egg width $(p<0.01)$, shell weight and egg width $(p<0.01)$ and some significant negative correlation between shell thickness and egg weight $(\mathrm{p}<0.05)$,shell thickness and egg length $(\mathrm{p}<0.01)$.

Table 1: Egg quality traits of nine phenotypes of local Chickens

\begin{tabular}{|c|c|c|c|c|c|c|c|c|c|c|c|}
\hline Parameters & 1 & 2 & 3 & 4 & 5 & 6 & 7 & 8 & 9 & SEM & SEM \\
\hline Egg weight $[\mathrm{g}]$ & $45.04^{\mathrm{a}}$ & $41.90^{\mathrm{b}}$ & $40.81^{b c}$ & $41.59^{\mathrm{b}}$ & $41.66^{\mathrm{b}}$ & $39.64^{b c}$ & $40.71^{\mathrm{bc}}$ & $37.80^{\mathrm{c}}$ & $38.44^{\mathrm{bc}}$ & $2.14 * *$ & $1.11 * *$ \\
\hline Egg length $[\mathrm{cm}]$ & $5.05^{\mathrm{a}}$ & $4.98^{\mathrm{bc}}$ & $4.96^{\mathrm{bc}}$ & $5.29^{\mathrm{ab}}$ & $5.38^{\mathrm{a}}$ & $4.96^{\mathrm{bc}}$ & $5.04^{\mathrm{abc}}$ & $4.85^{\mathrm{c}}$ & $4.92^{\mathrm{bc}}$ & $0.17 *$ & $0.11 *$ \\
\hline Egg width $[\mathrm{cm}]$ & $3.95^{\mathrm{a}}$ & $3.78^{b}$ & $3.76^{\mathrm{b}}$ & $3.94^{\mathrm{a}}$ & $3.70^{\mathrm{b}}$ & $3.74^{b}$ & $3.76^{\mathrm{b}}$ & $3.66^{\mathrm{b}}$ & $3.69^{b}$ & $0.10^{* * *}$ & $0.06^{* *}$ \\
\hline Egg index $[\%]$ & $77.61^{\mathrm{ab}}$ & $76.25^{\mathrm{ab}}$ & $76.09^{\mathrm{ab}}$ & $79.69^{\mathrm{a}}$ & $74.18^{\mathrm{b}}$ & $74.71^{\mathrm{b}}$ & $75.90^{\mathrm{ab}}$ & $73.80^{\mathrm{b}}$ & $74.79^{\mathrm{b}}$ & $1.85^{*}$ & $1.21 *$ \\
\hline $\begin{array}{l}\text { Albumin height } \\
{[\mathrm{mm}]}\end{array}$ & $6.51^{b}$ & $9.19^{\mathrm{a}}$ & $7.41^{b}$ & $6.80^{\mathrm{b}}$ & $7.43^{b}$ & $7.51^{b}$ & $6.66^{\mathrm{b}}$ & $7.11^{b}$ & $7.03^{b}$ & $0.79 * * *$ & $0.36^{* * *}$ \\
\hline $\begin{array}{l}\text { Albumin width } \\
{[\mathrm{mm}]}\end{array}$ & $6.25^{\mathrm{a}}$ & $5.31^{\mathrm{cd}}$ & $5.70^{\mathrm{bc}}$ & $6.01^{\mathrm{ab}}$ & $5.76^{\mathrm{b}}$ & $5.84^{\mathrm{ab}}$ & $5.86^{\mathrm{ab}}$ & $5.26^{\mathrm{d}}$ & $5.19^{d}$ & $0.36 * * *$ & $0.15 * * *$ \\
\hline York height $[\mathrm{mm}]$ & $1.60^{\mathrm{ab}}$ & $1.67^{\mathrm{a}}$ & $1.46^{\mathrm{bc}}$ & $1.67^{\mathrm{a}}$ & $1.45^{\mathrm{c}}$ & $1.60^{\mathrm{ab}}$ & $1.60^{\mathrm{ab}}$ & $1.53^{\mathrm{ab}}$ & $1.55^{\mathrm{abc}}$ & $0.08^{* *}$ & $0.06^{* *}$ \\
\hline York width $[\mathrm{mm}]$ & 3.90 & 3.90 & 4.00 & 3.86 & 3.90 & 3.85 & 3.84 & 3.90 & 3.86 & $0.05 \mathrm{NS}$ & $0.11 \mathrm{NS}$ \\
\hline York index [\%] & $41.64^{\mathrm{abc}}$ & $43.61^{\mathrm{ab}}$ & $36.45^{\mathrm{d}}$ & $45.92^{\mathrm{a}}$ & $37.78^{\mathrm{cd}}$ & $42.89^{\mathrm{abc}}$ & $41.72^{\mathrm{abc}}$ & $39.35^{\mathrm{bcd}}$ & $39.99^{\mathrm{bcd}}$ & d $2.97 * *$ & $1.52 * *$ \\
\hline Shell weight $[\mathrm{g}]$ & $5.11^{\mathrm{a}}$ & $4.06^{\mathrm{b}}$ & $4.01^{b}$ & $4.01^{b}$ & $4.24^{\mathrm{b}}$ & $3.69^{\mathrm{b}}$ & $4.13^{b}$ & $3.63^{\mathrm{b}}$ & $3.99^{\mathrm{b}}$ & $0.43 * *$ & $0.19 *$ \\
\hline $\begin{array}{l}\text { Shell thickness } \\
{[\mathrm{mm}]}\end{array}$ & .45 & .41 & .59 & .53 & .53 & .54 & .45 & .53 & .54 & $0.06 \mathrm{NS}$ & $0.06 \mathrm{NS}$ \\
\hline Haugh & $85.13^{c}$ & $100.50^{\mathrm{a}}$ & $91.30^{\mathrm{bc}}$ & $91.86^{\mathrm{c}}$ & $91.06^{\mathrm{bc}}$ & $92.18^{\mathrm{b}}$ & $90.35^{\mathrm{bc}}$ & $90.54^{\mathrm{bc}}$ & $89.96^{\mathrm{bc}}$ & $3.99 * *$ & $4.85 * *$ \\
\hline
\end{tabular}

$1=$ Frizzle $\mathrm{x}$ Frizzle, $2=$ frizzle naked neck, $3=$ frizzle smooth, $4=$ naked neck $\mathrm{x}$ naked neck, $5=$ naked neck frizzle, $\quad 6=$ naked neck $\mathrm{x}$ smooth, $7=$ smooth $\mathrm{x}$ smooth, $8=$ smooth $\mathrm{x}$ naked neck, $9=$ smooth $\mathrm{x}$ frizzle. Means on the row with different superscripts are significantly different. *: $\mathrm{P}<0.05,{ }^{* *}: \mathrm{P}<0.01,{ }^{* * *}: \mathrm{p}<0.001$

Table 2: Phenotypic Correction between External and Internal egg quality traits for Frizzle

\begin{tabular}{lllllll}
\hline $\begin{array}{l}\text { Internal egg } \\
\text { traits }\end{array}$ & Egg weight & Egg length & Egg width & Egg index & Shell weight & Shell thickness \\
\hline $\begin{array}{l}\text { Albumin } \\
\text { height }\end{array}$ & -0.38 & -0.16 & $-0.59 * *$ & -0.37 & -0.36 & -0.24 \\
Albumin width & -0.16 & -0.05 & 0.30 & 0.27 & 0.35 & 0.10 \\
Yolk height & 0.34 & 0.26 & 0.30 & 0.05 & 0.07 & $-0.41^{*}$ \\
Yolk width & 0.19 & 0.40 & 0.30 & -0.40 & 0.26 & 0.17 \\
Yolk index & 0.22 & -0.06 & -0.01 & 0.27 & -0.09 & $-0.44^{*}$ \\
Haugh unit & $-0.47 *$ & -0.24 & $-0.66 * *$ & -0.35 & $-0.44 *$ & -0.19 \\
\hline
\end{tabular}

*: $\mathrm{P}<0.05, * *: \mathrm{P}<0.01$

Table 3: Phenotypic Correction between Internal egg quality traits for Frizzle Internal Egg Traits

\begin{tabular}{llllll}
\hline \multicolumn{7}{l}{ Internal Egg Traits } & \multicolumn{1}{c}{} & & \\
& Albumin height & Albumin width & Yolk height & Yolk width & Yolk index Haugh unit \\
\hline Albumin height & 1.00 & & & & \\
Albumin width & $-0.64 * *$ & 1.00 & & & \\
Yolk height & -0.25 & -0.21 & 1.00 & & \\
Yolk width & -0.11 & -0.02 & -0.29 & 1.00 & 1.00 \\
Yolk index & 0.28 & -0.14 & $0.83 * *$ & $-0.76^{* *}$ & 0.25 \\
Haugh unit & $0.98 * *$ & $-0.64 * *$ & 0.20 & -0.12 & 1.00 \\
\hline
\end{tabular}

$*: \mathrm{P}<0.05, * *: \mathrm{P}<0.01$ 
Table 4: Phenotypic Correction between External egg quality traits for Frizzle

\begin{tabular}{llllll} 
& Egg weight & Egg length & Egg width & Egg index & Shell weight \\
\hline & & & & \\
Egg weight $(\mathrm{g})$ & 1.00 & & & & \\
Egg length & $0.85 * *$ & 1.00 & & & 1.00 \\
Egg width & $0.83 * *$ & $0.51 *$ & 1.00 & -0.25 & -0.05 \\
Egg index & -0.03 & $-0.49 *$ & $0.44 *$ & -0.04 & 1.00 \\
Shell weight & $0.85 * *$ & $0.82 * *$ & $0.60 * *$ & -0.13 & \\
Shell thickness & -0.19 & -0.04 & & & \\
\end{tabular}

$*: \mathrm{P}<0.05, * *: \mathrm{P}<0.01$

Table 5: Phenotypic Correction between External and Internal egg quality traits for Naked neck

\begin{tabular}{|c|c|c|c|c|c|c|}
\hline \multirow[t]{2}{*}{ Internal egg traits } & \multicolumn{6}{|c|}{ External egg Traits } \\
\hline & Egg weight & Egg length & Egg width & Egg index & Shell weight & Shell thickness \\
\hline Albumin height & $0.67 * *$ & 0.23 & $0.45 * *$ & 0.29 & $0.71 * *$ & $0.54 * *$ \\
\hline Albumin width & 0.21 & 0.25 & 0.36 & 0.29 & -0.08 & -0.04 \\
\hline Yolk height & $0.54 * *$ & 0.13 & $0.69 * *$ & $0.42 *$ & 0.37 & 0.34 \\
\hline Yolk width & $0.63 * *$ & $0.55 * *$ & $0.58 * *$ & 0.36 & $0.46 *$ & $0.41 *$ \\
\hline Yolk index & 0.26 & 0.03 & $0.56 * *$ & 0.37 & 0.06 & 0.09 \\
\hline Haugh unit & $0.73 * *$ & 0.35 & $0.74 * *$ & $0.57 * *$ & $0.68 * *$ & $0.54 * *$ \\
\hline
\end{tabular}

*: $\mathrm{P}<0.05, * *: \mathrm{P}<0.01$

Table 6: Phenotypic Correction between Internal egg quality traits for naked neck Internal Egg Traits

Albumin height Albumin width Yolk height Yolk width Yolk index Haugh unit

\begin{tabular}{|c|c|c|c|c|c|c|}
\hline Albumin height & 1.00 & & & & & \\
\hline Albumin width & -0.08 & 1.00 & & & & \\
\hline Yolk height & $0.48 *$ & 0.12 & 1.00 & & & \\
\hline Yolk width & 0.30 & $0.53 b^{* *}$ & 0.19 & 1.00 & & \\
\hline Yolk index & 0.23 & 0.04 & -0.09 & $0.88 * *$ & 1.00 & \\
\hline Haugh unit & $0.91 * *$ & 0.08 & $0.46 *$ & $0.63 *$ & $0.41 * *$ & 1.00 \\
\hline
\end{tabular}

Table 7: Phenotypic Correction between External egg quality traits for naked neck

\begin{tabular}{llllll}
\hline External Egg Traits & & & & \\
& Egg weight & Egg length & Egg width & Egg index & $\begin{array}{c}\text { Shell weight } \\
\text { Shell } \\
\text { thickness }\end{array}$ \\
\hline Egg weight $(\mathrm{g})$ & 1.00 & & & & \\
Egg length & $0.60^{* *}$ & 1.00 & & & \\
Egg width & $0.71^{* *}$ & $0.50^{*}$ & 1.00 & 1.00 & 1.00 \\
Egg index & 0.29 & 0.09 & $0.72^{* *}$ & 0.24 & $0.77^{* *}$ \\
Shell weight & $0.91^{* *}$ & $0.49^{*}$ & $0.56^{* *}$ & 0.39 & 1.00 \\
Shell thickness & $0.68^{* *}$ & 0.26 & $0.48^{* *}$ & & \\
\hline
\end{tabular}

$*: \mathrm{P}<0.05, * *: \mathrm{P}<0.01$ 
Table 8: Phenotypic Correction between External and Internal egg quality traits for smooth feathered

\begin{tabular}{|c|c|c|c|c|c|c|}
\hline \multirow{2}{*}{$\begin{array}{l}\text { Internal egg } \\
\text { traits }\end{array}$} & \multicolumn{6}{|c|}{ External egg Traits } \\
\hline & Egg weight & Egg length & Egg width & Egg index & Shell weight & Shell thickness \\
\hline Albumin height & -0.34 & $-0.41 *$ & -0.30 & 0.15 & $-0.41 *$ & $0.61 * *$ \\
\hline Albumin width & $0.69 * *$ & 0.38 & $0.50^{*}$ & 0.01 & $0.65 * *$ & -0.39 \\
\hline Yolk height & $0.43 *$ & -0.08 & 0.33 & 0.17 & 0.26 & 0.09 \\
\hline Yolk width & 0.18 & 0.26 & 0.18 & -0.21 & 0.04 & -0.31 \\
\hline Yolk index & 0.15 & -0.17 & 0.19 & 0.29 & 0.09 & 0.19 \\
\hline Haugh unit & -0.16 & $-0.44 * *$ & -0.10 & 0.10 & -0.29 & $0.59 * *$ \\
\hline
\end{tabular}

$*: \mathrm{P}<0.05, * *: \mathrm{P}<0.01$

Table 9: Phenotypic Correction between Internal egg quality traits for smooth feathered

Internal Egg Traits

\begin{tabular}{|c|c|c|c|c|c|c|}
\hline & Albumin height & Albumin width & Yolk height & Yolk width & Yolk index & Haugh unit \\
\hline Albumin height & 1.00 & & & & & \\
\hline Albumin width & $-0.55 * *$ & 1.00 & & & & \\
\hline Yolk height & -0.07 & 0.29 & 1.00 & & & \\
\hline Yolk width & -0.33 & 0.13 & $-0.45 *$ & 1.00 & & \\
\hline Yolk index & 0.15 & 0.10 & $0.83 * *$ & $-0.83 * *$ & 1.00 & \\
\hline Haugh unit & $0.90 * *$ & -0.35 & 0.10 & -0.39 & 0.29 & 1.00 \\
\hline
\end{tabular}

*: $\mathrm{P}<0.05, * *: \mathrm{P}<0.01$

Table 10: Phenotypic Correction between External egg quality traits for smooth feathered

\begin{tabular}{lllllll}
\hline External Egg Traits & Egg weight & Egg length & Egg width & Egg index) & Shell weight & Shell thickness \\
\hline Egg weight $(\mathrm{g})$ & 1.00 & & & & \\
Egg length & $0.53 * *$ & 1.00 & & & \\
Egg width & $0.79 * *$ & -0.26 & 1.00 & & 1.00 & 1.00 \\
Egg index & 0.21 & 0.27 & $0.56 * *$ & 0.28 & -0.33 \\
Shell weight & $0.47^{*}$ & 0.40 & $0.41^{* *}$ & 0.28 & \\
Shell thickness & $-0.41^{*}$ & $-0.76^{* *}$ & -0.24 & 0.19 &
\end{tabular}

\section{Discussion}

The average mean egg weight (45.04) produced by frizzle phenotype obtained in this study is higher than the results obtained elsewhere (Palmar et al., 2006 and Momoh et al., 2010), who studied egg quality traits in Kadaknath breeds and ecotype in Nigerian local chickens respectively. The result is lower than values obtained in Egyptian Bandra and Gimmizah local chickens (Yousria et al., 2010). Raji et al. (2009) also reported higher values in unspecified Nigerian local chickens. Age, feed protein levels and temperature are some of the factors adduced to affect the egg size (Benerjee, 1992). The heavier egg produced by frizzle feathered chicken is probably due to the favorable gene effect on production (Merat, 1990) The mean egg length obtained by naked neck and naked neck frizzle in the study is slightly higher than value (5.15) reported by (Yakubu et al., 2008), in Nigerian naked neck and it compares favorably with the values recorded for heavy and light ecotypes and their $\mathrm{F}_{\mathrm{i}}$ crosses in Nigeria (Momoh et al., 2010).The result is also slightly higher than values (4.83) reported for Bangladesh indigenous chickens (Saiful Islam and Ripon Kumar Dutta, 2010). The mean value of egg width produced by frizzle feathered in the present study is slightly higher than (Yakubu et al., 2008). Egg shape index is an indicator of external egg quality. The values produced by naked neck is slightly higher than (74.68) and (72.60) for naked neck and Normal feathered respectively (Yakubu et al., 2008).The higher shape index in the study is due to the factors earlier mentioned above and also due to heat dissipation and improved thermoregulation resulting to a better relative heat tolerance under hot climates and of genetic constitution of the chicken. Furthermore the higher shape index produced by the naked neck further consolidated their superiority over the remaining local chicken phenotypes in Nigeria. The mean yolk index produced by the naked neck in this study is slightly higher than values reported (Palmar et al., 2006; Momoh et 
al., 2010), but slightly lower than values reported (Ikeobi et al., 1999), from unnamed phenotypes in Nigerian local chickens and closely similar to the result reported (Yousria et al., 2010; Olunede and Longe, 2002; Chineke, 2001; Ukachukwu and Akpan, 2007). The mean albumin height in the study is higher than the result reported by Fayeye et al., 2005; Nonga et al., 2010; Momoh et al., 2010. Generally albumin has a major influence on overall in terms of egg quality and large proportion of thick white indicating high quality and it ultimately will have high haugh unit.

Highest Yolk index produced by naked neck obtained in this study is far higher than values reported (Palmar et al., 2006), but compared favorably with the results reported for heavy, and light ecotypes and its reciprocal crosses (Momoh et al., 2010). The result is also similar to values reported for Egyptian Bandara and Gimmizah, but slightly lower than Bandara and Gimmizah crosses.

The mean value of shell weight obtained in frizzle feathered in the present study is lower than values reported by (Yousria et al., 2010) on Egyptian strains of local chickens, but the findings compares favourably (Momoh et al., 2010; Nonga et al., 2010 and Saiful Islam and Ripon Kumar Dutta, 2010).The lower weight recorded in this study is probably due to the efficacy of the weighing Machine used, the methods of drying of the shell employed and probably differences in rearing systems. The main chemical component of egg shell is calcium which may have different levels in the feed.

Shell thickness did not show significant difference among the phenotypes studied. However, eggs with thick shell wall are desirable to withstand externally applied force, thus preventing breakage of egg and this is and economic indicator for commercially poultry producers and consumers. The result obtained in this study is higher than the values reported (Padhi et al., 1998; Yakubu et al., 2008; Momoh et al., 2010; Palmar et al., 2010; Yousria et al., 2010). naked neck produced heavier shell weight than the remaining phenotypes. The result obtained in this study is comparable to light ecotype reported (Momoh et al., 2010; Nonga et al., 2010), but slightly lower than values produced by heavy ecotypes (Momoh et al., 2010).The results is also slightly lower than the result reported by (Yousria et al., 2010) in Egyptian Bandra and Gimmizah and its crosses.

Highest haugh unit produced by frizzle naked neck obtained in this study is far higher than the average haugh unit reported by (Palmar et al., 2006) in Kadaknath breeds. The result is also higher than values reported for some indigenous backyard poultry elsewhere (Ikeobi et al., 1999; Chatterije et al., 2006; Niranjan et al., 2008; Yousria et al., 2010; Momoh et al., 2010). Since haugh unit is the measure of albumin quality which determines the quality of the egg. The higher haugh unit obtained in the study indicated superior albumin in all the phenotypes studied. Similarly it is an indication that the research was conducted on middle age class chickens with good quality fresh eggs and free from infectious diseases like ND. Haugh unit and yolk index are the indicators of internal egg quality (Isikwenu et al., 1999). The higher the yolk index Ayorinde, (1987) and the haugh unit, the more the desirable the egg quality (Fayeye et al., 2005).

\section{Correlation of different Egg quality traits:}

Statistically significant positive correlation recorded in the present study between albumin height, yolk width and haugh unit with egg weight; yolk width and egg length; albumin height, yolk height, yolk width haugh with egg width; albumin height, yolk width, haugh unit with shell weight, yolk width and shell thickness are in agreement with (Yakubu et al., 2008) in naked neck and Smooth feathered type of local chickens in Nigeria (Table 5). Similarly significant positive correlation obtained in naked neck and Smooth feathered chickens in this study between albumin height and shell thickness and haugh and shell thickness are in harmony with (Yakubu et al., 2008). Furthermore the result recorded in this study in Smooth feathered chickens between albumin width and egg weight, albumin width and egg width and albumin width and shell weight are consistent with the finding of (Olawumi and Ogunlade, 2008). The negative correlation value between albumin height and shell weight in smooth feathered phenotype concurs with (Yakubu et al., 2008). Similarly the negative correlation obtained between haugh unit and egg length is comparable with (Yousria et al., 2010), who reported non significant, but negative correlation value (Table 8).

Significant positive correlation between egg length and egg weight, egg width and egg weight, shell weight and egg weight, shell weight and egg width, egg index and egg width, in all the three phenotypes compares favorably with (Yakubu et al., 2008, Olawumi and Ogunlade, 2008, Yousria et al., 2010).In this study egg width is indicated to be good estimator of egg shape index. Yannakopoulos and Tserveni-Gousi, (1986) reported that egg shape index could be used as a criterion for determining stiffness of eggshell. Furthermore the values between egg width and egg length in naked neck and frizzle feathered chickens agreed with (Yakubu et al., 2008; Olawumi and Ogunlade, 2008, Yousria et al., 2010).

The values recorded between shell weight and egg length in naked neck and frizzle agreed with (Olawumi and Ogunlade, 2008, Yousria et al., 2010). Also the result obtained between egg weight and shell weight, egg weight and shell thickness in naked neck is inconsonance with (Yakubu et al., 2008). Kul and Seker, (2004) reported that egg weight has an indirect relation ship with shell quality of the egg. Thus it has been stated by most of the researchers that the egg shell thickness has a direct relation with the egg weight (choi 
et al., 1983) and has positively significant correlations with the shell weight (Faroog et al., 2001).It has been considered that the eggshell quality would be determined by using egg weight values due to the positive and significant correlation determined between the egg weight and shell thickness and the shell weight. Similarly, Ozcelik, (2002) in his study, has reported that the egg weight values would be used instead for determining the shell quality, because the shell thickness and the shell weight would be measured after breaking the egg. The phenotypic correlation value obtained between the egg weight and shell thickness in the study is higher compared to 0.05 reported Olawumi and Ogunlade, (2008) in exotic Isa brown layers and higher than 0.26 reported by Stadelman, (1986). This implies that egg weight has a strong association with shell thickness in this phenotype of chickens. The values recorded between shape index and the shell weight in naked neck and smooth feathered types is consistent with (Olawumi and Ogunlade, 2008). Therefore shell weight could not be considered as good estimator of egg shape index.

The negatively correlated values in this study recorded between albumin width and albumin height, in frizzle and smooth feathered agreed with (Olawumi and Ogunlade, 2008). Similarly, yolk index and yolk width is in agreement with (Yakubu et al., 2008).Furthermore albumin and yolk height with haugh unit in all the three phenotypes is in agreement with Yakubu et al. (2008) in Nigerian smooth and naked neck chickens. Also the result obtained between haugh unit and albumin height in frizzle chicken agreed with (Olawumi and Ogunlade, 2008). Yolk width and yolk height in smooth feathered chickens disagreed with (Yakubu et al., 2008). The values between haugh unit and yolk index in naked neck is consonance with (Kul and Seker, 2004) in Japanese quails.

\section{Conclusions:}

The egg quality traits were significantly affected by the type of phenotypes except yolk width and shell thickness. Frizzle feathered consistently produced heavier, longer, wider egg and albumin and heavier shell. Similarly frizzle naked neck produced higher albumin and yolk height and haugh unit. Furthermore naked neck produced higher egg width, egg and yolk index and yolk height. Frizzle and Smooth feathered chickens produced some significant positive and negative correlations in egg quality traits and Naked neck produced significant positive correlation in all the egg quality traits studied.

\section{References}

[1]. Adebayo A. A. and Tukur A. L. (1999), Adamawa State in maps department of geography Federal University of Technology Yola in cooperation with paraclete publishers Yola, Nigeria pp $23-26$.

[2]. Alabi O.J. Ng'ambi J.W and Norris D (2012) Effect of Egg Weight on Physical Egg Parameters and Hatchability of Indigenous Venda Chikens. Asian Journal of Animal and Veterinary Advances 7: 166 -172.

[3]. Arima, Y., Mather, F.B., and Ahmad, M.M., (1976) Response of egg production and shell quality to increases in environmental temperature in two age groups of hens. Poultry Science 55: 818-820.

[4]. Arscott, G.H., Rachapaetayakom, P, Benier, P. E. and Adams, F.W., (1962). Influence of ascorbic acid, calcium and phosphorus on specific gravity of eggs. Poultry Science, 41: 485 - 488.

[5]. Ayorinde, K. L. (1978). Physical and chemical characteristic of the eggs of four indigenous guinea fowls in Nigeria. Journal of Animal Production, 14: 125-128

[6]. Ayorinde, K. L and Oke, U. K (1995). The influence of juvenile body weight and two feeding regimes during the growing phase on growth and early lay characteristics of pullets. Nigerian Journal of Animal Production, 22: 101-107.

[7]. Balnave, D., Yoselewitz, I. and Dixon R. J. (1989). Physiological changes associated with the production of defective eggshells by hens receiving sodium chloride in the drinking water. British Journal of Nutrition, 61, 35-43.

[8]. Chatterjee, R.N., Sharma R.P., Niranjan, M., Reddy and Mishra A. (2006). Genetic studies on egg quality traits in different White Leghorn population. In J. Anim. Genet. Breeding, 27: 51-54.

[9]. Chineke, C.A., (2001). Interaction existing between body weight and egg production traits in Olympia Black Layers. Nig. Anim. Production, 28: 1-6.

[10]. Chrysostome, C. A. A. M., Bell J G., Demey F and Verhulst A, (1995) Seroprevalencies to three diseases in village chickens in Benin. Preventive Veterinary Medicine, 22:257-261.

[11]. Clunies, M., Parks, D. and Leeson, S., (1992). Calcium and phosphorus metabolism and eggshell thickness in laying hens producing thick or thin shells. Poultry Science, 75, 656- 663.

[12]. Curtis, P. A., Gardner, F. A. and Mellor, D. B., (1985). A Comparison of Selected Quality and Compositional Characteristics of Brown and White shell eggs. 2. Interior Quality. Poultry Science, 64, 302 - 306.

[13]. Doyon,G., Bernier-Cardou, M., Hamiliton, R. M. G., Castaigne, F. and Randall, C. J., (1986). Egg quality 2. Albumen quality of eggs from five commercial strains of White Leghorn hens during one year of lay. Poultry Science, 65: 63-66.

[14]. Duyck, S. K., Miles, R. d., Rossi, A. F. and Henry, P. R., (1990). Effect of time and storage conditions on interior egg quality from hens fed vanadium. Poultry Science, 69, (Supplement 10), 164.

[15]. Fayeye, T. R., Adeshiyan, A. B and Olugbami, A. A. (2005) Egg traits, hatchability and early growth performance of the Fulaniecotype Livestock Research for Rural Development. 17 (8): 1-7

[16]. Gueye, E. F, (1998). Village egg and fowl meat production in Africa Worlds Poultry Sciences Journal, 54: 73-86.

[17]. Hamilton, R. M. G (1982). Methods and Factors that affects the measurement of egg shell quality. Poultry Science, 61: $2022-2039$.

[18]. Hess, J. B and Britton, W. M (1989). The effect of dietary chloride or protein changes on eggshell pimpling and shell quality in late production leghorn hens. Nutrition Reports International 40:1107 - 1115.

[19]. Ikeobi, C.O.N., Hyginus C.M., Adenowo J.A. and Adedambo, O.A. (1999). Egg quality characteristics of four local poultry species in Nigeria. Trop. J. Anim. Sci., 1:37-42.

[20]. Isikwenu, J. O., Okaplefe, C. S and Mmerole, F. U. C (1999). Storability of chickens eggs under different storage conditions. Proceedings of $26^{\text {th }}$ Annual Nigerian Society for Animal Production Conference, 21-25 march, Ilorin. 
[21]. Islam, M. A., Bulbuli, S. M., Seeland, G and Islam, A. B, (2001). Egg quality in different chicken genotypes in summer and winter. Pak. Journal of Biological Science, 4: 1411-1414.

[22]. Jones, D. R., (2006). Conserving and monitoring egg shell quality. Proceedings of the $18^{\text {th }}$ Annual Australian Poultry Science Symposium, pp. $157-165$.

[23]. Keshavarz, K. and Austic R. E., (1990). The effect of minerals on acid-base balance and eggshell quality. Journal of Nutrition, 120: 1360-1369.

[24]. Kul, S. and Seker, I. (2004). Phenotypic correlations between some external and internal egg quality traits in the Japaneese quail (Cortunix cortunix Japanica). Int. J. Poultry Science 3: $400-405$.

[25]. Merat P. (1990) Pleiotropic and associated effects of major genes In: Crawford R. D., (ed), Poultry breeding and genetics, Elsevier, Amsterdam. Pp. 442- 448

[26]. McCready, S. T., Roland, D. A., and Fry, J. L(1972). External quality, composition and defects of eggs from hens fed a calcium deficient diet. Poultry Science, 51:670 - 675.

[27]. Momoh, O. M., Ani A. O and Ugwuowu L. C (2010). Part-period Egg production and aegg quality characteristics of two Ecotypes of Nigerian Local chickens and Their $\mathrm{F}_{1}$ Crosses. International Journal of Poultry Science 9 (8): 744-748.

[28]. Niranjan, M., Shama, R.P., Rajkumar, U., Chatterjee, R.N., Reddy B.L.N., and Battacharya, T.K. (2008). Egg quality traits in chiken varieties developed for backyard poultry farming in Indian. Livestock Res. Rural Development., Vol., 20.

[29]. Nonga, H.E., Kajuna, F.F., Ngowi, H.A. Karimuribo, E.D. (2010). Physical egg quality characteristics of free-range local chickens in Morogoro municipality, Tanzania. Livestock Research for Rural Development 22 (12): 1-9

[30]. Nwosu, C. C. (1979). Characterization of the local chickens in Nigeria and its potentials for egg and meat production In poultry production in Nigeria, proceedings First National Seminar on poultry production, Ahmadu Bello University, Zaria, Pp 187-210.

[31]. Olawumi, S.O. and Ogunlade, J.T. (2008).Phenotype correlations between some External and Internal egg Quality traits in Exotic Isa Brown Layer Breeder. Asian Journal of Poultry Science, 2: 30 - 35.

[32]. Olori, V. E and Sonaiya, E. B (1992) Effect of length of lay of Nigerian indigenous chicken on their egg composition and shell quality. Nig. J. Animal Prod, 19: 95-100.

[33]. Okachukwu, S.N. and Akpan, V.O. (2007). Influence of level and duration of quantitative feed restriction on post-restriction egglaying characteristics and egg quality of pullets. International Journal of Poultry Science., 6: $567-572$.

[34]. Olurede, R.R. Longe O.G. (2002). Effect of replacing palm kernel cake on egg quality characteristics, haematology and serum chemistry of laying hens. Nigerian Journal of Animal Production, 27: 19-23.

[35]. Oluyemi,J.A and Roberts, F. A. (2000) Poultry production in worm and wet Climates. $2^{\text {nd }}$ Edn., spectrum Books, Ibadan, ISBN13:9789780290979, PP:190.

[36]. Omeje, S. S. and Nwosu, C. C. (1988) Utilization of the Nigerian chickens in poultry breeding: Assessment of heterosis in growth and egg production. Journal Animal and Genetics 105: 417-425.

[37]. Oni, O. O, Abubakar, B. Y., and Ogundipe, S.O. (1991) Genetic and phenotypic associations of juvenile body weights and egg production traits in two strains of Rhode Island chickens Nigeria Journal of Animal production 18: 66-70.

[38]. Padhi, M.K., Rai R.B., Senani S. and Saha S.K. (1998). Assessment of egg quality in different breads of chicken, Indian Journal of Poultry Science, 33: $113-115$.

[39]. Parmar, S N S., Thakur, M S., Tomar, S S., and Pillai, P V A (2006). Evaluation of egg quality traits in indigenous Kadaknath breeds of poultry. Journal of Livestock Research for Rural Development. $18: 9$.

[40]. Peters, S. O, Ikeobi, C. O. N., Ozoje, M. O., Famakinwa, O. A., Oshodi., Y. S and Adebambu, O. A. (2007). Egg quality of Nigerian local chicken as influenced by some major genes. Nigerian Journal of Animal Production. 34: 25-35.

[41]. Raji, A. O., Aliyu, J., Igwebuike, J. U and Chiroma, S (2009) Effect of storage methods and time on egg quality traits of laying hens in hot dry climate. ARPN Journal of Agriculture and Biological Science 4: 1 - 7.

[42]. Saiful Islam M and Ripon Kumar Dutta(2010). Egg Quality Traits of Indigenous, Exotic and Crossbreed Chickens (Gallus domesticus L) in Rajshahi, Bangladesh.Journal Life Earth Science, 5: 63-67.

[43]. Smith AJ (1990), The tropical Agriculture. Poultry (1 st ed) London and Basinstrove. The Macmilan press Ltd. Pp 218

[44]. Solomon, S.E., 1991, Egg and Eggshell Quality. Wolfe Publishing Ltd., London, England.

[45]. Tumova, E., Zita, L., Hubeny, M., Skrivan, M and Ledvinka, Z. (2007).The effect of oviposition time and genotype on egg quality characteristics in egg type hens. Czech. J Anim. Sci. 52: 26-30

[46]. Williams, K. C., (1992). Some factors affecting albumen quality with particular reference to Haugh unit score. World's Poultry Science Journal, 48: $5-16$.

[47]. Yakubu A. Oga O. M and Barde R. E (2008). Productivity and Egg Quality Characteristics of Free Range Naked Neck and Normal feathered Nigerian indigenous Chickens. International Journal of Poultry Science, 7 (6): 579-588.

[48]. Yalcin S., Testik A., Ozkan, S., Settar P., Celen F. and Cahaner A. (1997): Performance of naked neck and normal broilers in hot, warm, and temperate climates. Poultry Sci. Savoy, IL: Poultry Science Association. 76 (7) 930-937.

[49]. Yeasmin, Hussain, S.S and Hamid, M. A. (1992) Investigation on the qualities of egg on different genetic groups of birds in different season Bangladesh J .of Animal. Sciences 21: 29-35.

[50]. Zaghini, A., Martelli, G., Roncada, P., Simioli, M. and Rizzi, L.(2005). Mannanoligosaccharides and Aflatoxin B1 in Feed for Laying Hens: Effects on Egg Quality. Aflatoxins B1 and M1 residues in Eggs and Aflatoxin B1 levels in Liver. Poultry Science, 84: $825-832$. 